Article

\title{
Using Grass Cuttings from Sports Fields for Anaerobic Digestion and Combustion
}

\author{
Meike Nitsche, Frank Hensgen and Michael Wachendorf * \\ Department of Grassland Science and Renewable Plant Resources, Kassel University, Steinstrasse 19, \\ 37213 Witzenhausen, Germany; meike.nitsche@gmx.de (M.N.); hensgen@uni-kassel.de (F.H.) \\ * Correspondence: gnr@uni-kassel.de; Tel.: +49-5542-98-1242 \\ Academic Editor: Tariq Al-Shemmeri \\ Received: 24 January 2017; Accepted: 14 March 2017; Published: 18 March 2017
}

\begin{abstract}
Sports fields provide a recreation space for citizens, but also generate grass biomass, which is cut weekly during the main seasons and therefore could be used in energy generation (combustion or anaerobic digestion). To evaluate the technical suitability of the grass cuttings, silage was produced from four sports fields during one vegetation period and investigated for relevant properties. Potential methane yield was determined with batch tests. Mean methane yield was $291.861_{\mathrm{N}} \cdot \mathrm{kg}^{-1} \mathrm{VS}_{\text {added }}$ (VS, volatile solid). Neutral detergent fiber concentration was low $(44.47 \%$ $\mathrm{DM}$, dry matter), yet mineral concentration was high in comparison to grass types cut at a lower frequency. Concentrations of $\mathrm{Cl}, \mathrm{N}$, and S, which may lead to unfavorable emissions, fouling, and corrosion during combustion, were too high for an unproblematic combustion process. This was still the case even after applying a mineral-reducing pretreatment, which generates a fiber-rich press cake and a press fluid rich in easy soluble substances. Digestion of the press fluid led to methane yields of $340.10 \mathrm{l}_{\mathrm{N}} \cdot \mathrm{kg}^{-1} \mathrm{VS}_{\text {added }}$ and the press cake had a higher heating value of $19.61 \mathrm{MJ} \cdot \mathrm{kg}^{-1} \mathrm{DM}$, which is close to that of coniferous wood. It can be concluded that biomass from sports fields could be a suitable co-substrate in bio-energy generation.
\end{abstract}

Keywords: IFBB; urban biomass; biogas; turf grass; grass silage

\section{Introduction}

Sports fields are vital locations within cities. They not only offer a place for recreational activities, but also provide a setting for social interaction. To provide valuable sports fields, grass needs to be kept at a short height, which means implementing a mowing frequency of about 20 times a year [1]. Typically, sports fields in central Europe are cut every week from spring to autumn, and in the periods of main growth, biomass has to be removed and disposed of. Not only does disposal of this biomass contribute to general maintenance costs, it is also a waste of a potential substrate for bio-energy.

Grass has previously been considered for bio-energy generation. The main technologies are combustion, anaerobic digestion, and integrated approaches. Considering combustion, grass may cause corrosion, fouling, and pollutant emissions due to high mineral concentrations [2]. To estimate the risk of detrimental processes in combustion, indices that relate concentrations of different elements to possible predispositions of the fuel have been presented. For instance, the $\mathrm{K}_{2} \mathrm{O} / \mathrm{CaO}$ index indicates the risk of fouling [3], while the $2 \mathrm{~S} / \mathrm{Cl}$ index indicates the risk of corrosion [4]. In anaerobic digestion, grass may lead to clogging of pipes and may form layers in the reactor [5]. In addition, low methane yields have been reported, depending on the quality of the grass silage [6]. These problems are solved by the integrated generation of solid fuel and biogas from biomass (IFBB) process, which divides the material into a fiber-rich press cake for combustion and a press fluid rich in easily digestible organics for anaerobic digestion [7]. 
For all technologies, the maturity of the material is a crucial factor as it determines the energy potential. High maturity leads to lower methane yields but higher heating values in combustion $[6,8]$. Therefore, research on combustion has focused on rather old biomass, while research on anaerobic digestion concentrates on rather young biomass. However, when considering "young" biomass, cutting frequencies of three to four harvests a year are typically investigated (e.g., [9,10]). Information on chemical composition as well as the technique-related properties of grass biomass cut at higher frequencies is scarce. Triolo et al. [11] investigated anaerobic digestion of lawn grass cuttings, though no information on harvest date or cutting frequency was given. Methane yield was $332.7 \mathrm{l}_{\mathrm{N}} \cdot \mathrm{kg}^{-1}$ volatile solids (VS). However, the evaluation of the feasibility of biomass from sports fields in bioenergy generation calls for detailed knowledge of the biomass. Therefore, we present detailed data on silage from grass cuttings of sports fields. We measured (i) the chemical composition and (ii) the methane yield; and calculated (iii) heating values and (iv) indices relevant for combustion. Furthermore, we investigated (v) the effect of the integrated generation of solid fuel and biogas from the biomass process on the properties relevant in energy recovery.

\section{Results and Discussion}

\subsection{Elemental Composition of Silage and Press Cake}

Silage from sports fields contained high mineral concentrations in comparison to grass silage cut at a lower frequency (Figure 1). The difference was particularly pronounced for $\mathrm{Cl}$ (2.5 times higher) and $\mathrm{N}$ (3 times higher) compared to grass from urban roadside verges cut in July [12]. El-Nashaar [13] measured element concentrations in several temperate grasses at different maturity stages and found a significant effect of plant development stage. Stands prior to stem elongation showed concentrations of $\mathrm{Cl}$ higher than mature stands. The IFBB process reduced the $\mathrm{Cl}$ and $\mathrm{N}$ concentration significantly to $0.16 \%$ dry matter (DM) and $3.22 \% \mathrm{DM}$, respectively. For $\mathrm{Cl}$ and $\mathrm{N}$ concentrations, the relative reduction was $88 \%$ and $22 \%$, respectively, which is close to the relative reduction found for urban grass (90\% and 29\%, respectively [12]). McEniry et al. [14] found similar reduction rates for $\mathrm{Cl}(93 \%$, calculated from given data) after treating silage from Lolium perenne cut in May with a fractionation process including mechanical dehydration. In contrast to the IFBB technique, this fractionation process included a detergent and higher mashing temperatures as well as a longer mashing period, thereby achieving a higher $\mathrm{N}$ reduction (about $72 \%$, calculated from given data). The total $\mathrm{Cl}$ and $\mathrm{N}$ concentrations in the press cake derived by the IFBB technique were considerably above the guiding values given by Obernberger et al. [15] for an unproblematic combustion $(<0.1 \%$ and $<0.6 \% \mathrm{DM}$, respectively). However, by using an advanced and adapted boiler technique (e.g., air staging and selective (non-)catalytic reduction), the occurrence of $\mathrm{NO}_{x}$ emissions can be minimized [15].

The IFBB process reduced $\mathrm{K}, \mathrm{P}, \mathrm{Na}$, and $\mathrm{Zn}$ concentrations significantly. The relative reduction of $\mathrm{K}$ was about $83 \%$, though with greater effort, a relative reduction rate of about $98 \%$ (calculated from given data) could be achieved by treating silage from Lolium perenne cut in May [14]. In our study, the mean concentrations of $\mathrm{K}, \mathrm{P}, \mathrm{Na}$, and $\mathrm{Zn}$ in the press cake from sports fields were higher than in the press cake from urban roadside verges. This pattern was also given for $\mathrm{S}$, which had a twofold and fivefold increase in concentration in silage and press cake, respectively, from sports fields in comparison to grass cuttings from urban roadside verges [12]. The higher S, P, and $\mathrm{K}$ concentrations in silage from sports fields compared to roadside verges are in accordance with the findings of El-Nashaar et al. [13], who detected a significant effect of plant maturity on these elements. While K concentrations of Bromus marginatus and Laymus cinereus in stands prior to stem elongation were in accordance with our findings, $\mathrm{S}$ and $\mathrm{P}$ concentrations were lower than the values detected for sports fields in our study. $\mathrm{S}$ concentration in the press cake from sports fields was $0.27 \% \mathrm{DM}$, which exceeds the guiding value of Obernberger et al. [15] for an unproblematic combustion $(<0.1 \% \mathrm{DM})$. 
The difference in mineral concentration between the two urban biomasses (sports fields and roadside verges) was less distinct for $\mathrm{Ca}$ and $\mathrm{Mg}$. The IFBB process reduced the concentration of both elements significantly.
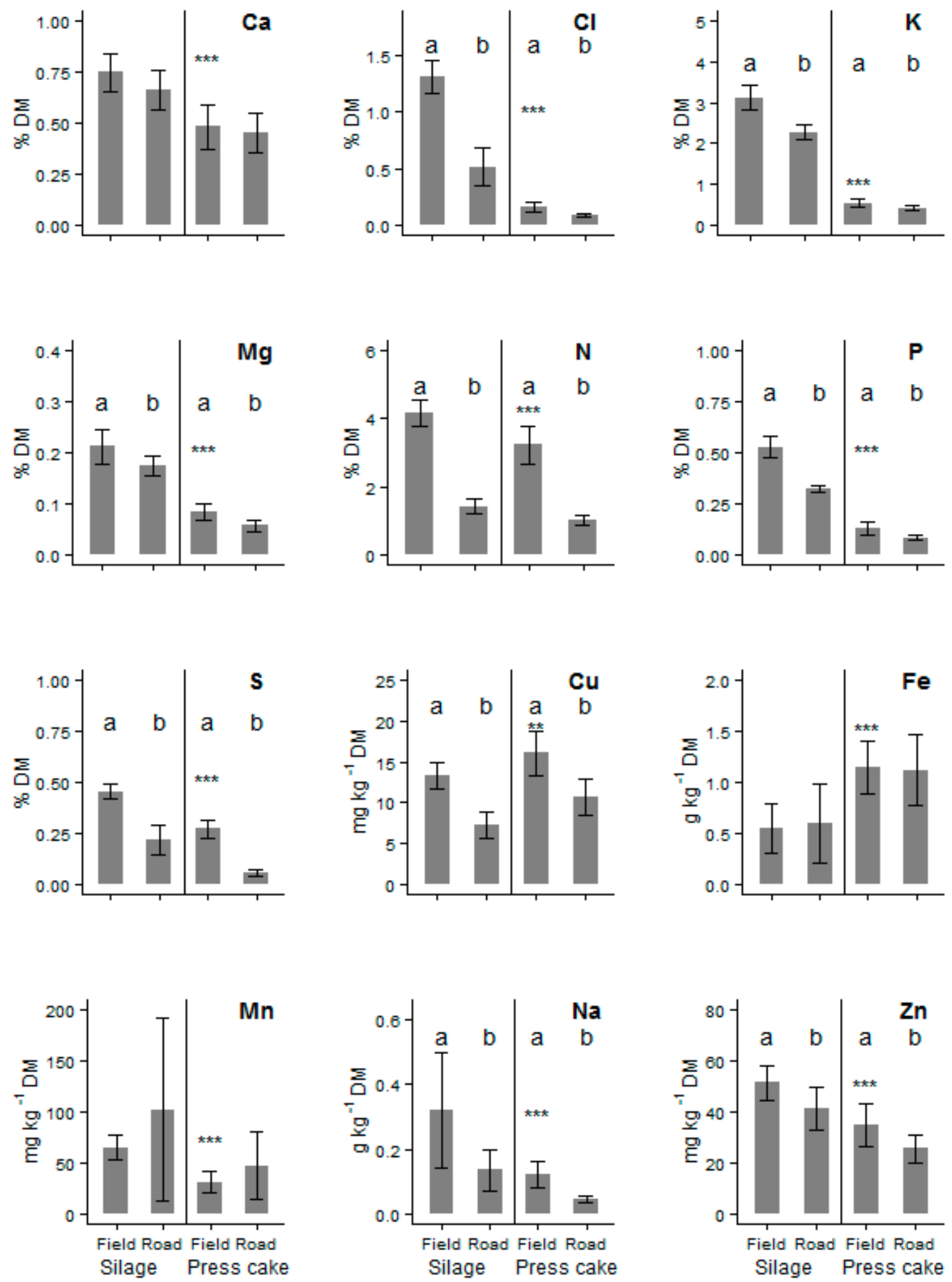

Figure 1. Element concentrations in grass from sports fields and urban roadside verges ( 2 cuts) for comparison. Data for urban roads are taken from [12], apart from Fe data, which are based on own measurements. The letters ( $a$ and $b$ ) indicate significant differences between silages and press cakes of different proveniences. Asterisks indicate significant differences between the silage and press cake of sports fields $\left(* *, p<0.01 ;{ }^{* *}, p<0.001\right)$. 
In contrast to the other elements, Fe and Mn concentrations were lower in silage from sports fields compared to roadside verges. However, this difference was not significant. The Mn concentration was reduced by the IFBB process. In contrast, concentrations of $\mathrm{Fe}$ and $\mathrm{Cu}$ increased significantly. For $\mathrm{Cu}$, Piepenschneider et al. [12] also detected a concentration increase by the IFBB process, which was hypothesized to be due to the abrasion of machinery made from $\mathrm{Cu}$-containing stainless steel.

The added potable water would be another possible source for additional $\mathrm{Cu}$. However, the $\mathrm{Cu}$ concentration of the used water was below the detection limit of $0.001 \mathrm{mg} \cdot \mathrm{L}^{-1}$. As a third possible explanation for the increased $\mathrm{Cu}$ and Fe concentrations in the press cake, it has to be considered that these elements might not be released as easy as the other minerals into the press fluid and might be retained in the solid phase. However, bare washing of leaf litter biomass showed a clear decrease in $\mathrm{Cu}$ concentration [16]. Additional research is required to fully understand why Fe and $\mathrm{Cu}$ concentrations increase in the press cake.

However, $\mathrm{Cu}$ concentrations in material from sports fields were lower compared to material from roadside verges. Additionally, $\mathrm{Zn}$ concentrations in the silage and press cake from sports fields were lower than values for the material from roadside verges [12] and were reduced by the IFBB procedure.

The mixed model procedure could not detect a significant effect of harvest date for single element concentrations. Therefore, a constant biomass quality can be expected.

\subsection{Combustion Related Properties of Silage and Press Cake}

C concentration in silage from sports fields was similar to the concentration detected in grass silage from urban roadside verges (Table 1). C concentration (DM) in the press cake from sports fields was $2.64 \%$ higher than in the corresponding silage, but $2.6 \%$ lower than in coniferous wood [15]. In contrast, $\mathrm{H}$ concentration in silage and press cake from sports fields was lower than in grass silage and press cakes from roadside verges, as well as in coniferous wood. Ash concentration was significantly reduced by the IFBB process, from $14.54 \% \mathrm{DM}$ in silage to $7.60 \% \mathrm{DM}$ in the press cake. This is considerably higher than the ash concentration in coniferous wood, but in the range of known values for grass (e.g., Lolium perenne: $8.4 \%$ DM, Phleum pratense: 7.6\% DM when harvested in mid-May [17]).

Table 1. Combustion related properties of grass from urban proveniences and coniferous wood. Standard deviations are given.

\begin{tabular}{|c|c|c|c|c|c|}
\hline & $\begin{array}{l}\text { Silage from } \\
\text { Sports Field }\end{array}$ & $\begin{array}{l}\text { Press Cake from } \\
\text { Sports Field }\end{array}$ & $\begin{array}{l}\text { Silage from } \\
\text { Urban Roadside } \\
\text { Verges }{ }^{1}\end{array}$ & $\begin{array}{c}\text { Press Cake from } \\
\text { Urban Roadside } \\
\text { Verges }{ }^{1}\end{array}$ & $\begin{array}{c}\text { Coniferous } \\
\text { Wood without } \\
\text { Bark }^{2}\end{array}$ \\
\hline Number of samples & 18 & 18 & 10 & 10 & not given \\
\hline$C(\% \mathrm{DM})$ & $45.76 \pm 1.01^{\mathrm{b}}$ & $48.40 \pm 1.28^{\mathrm{a}}$ & 45.72 & 46.66 & 51 \\
\hline $\mathrm{H}(\% \mathrm{DM})$ & $5.37 \pm 0.09^{b}$ & $5.98 \pm 0.18^{\mathrm{a}}$ & 6.35 & 6.43 & 6.3 \\
\hline Ash (\% DM) & $14.54 \pm 2.02^{\mathrm{a}}$ & $7.60 \pm 2.00^{b}$ & 10.84 & 6.89 & 0.3 \\
\hline $\mathrm{K}_{2} \mathrm{O} / \mathrm{CaO}$ & $3.66 \pm 0.68^{\mathrm{a}}$ & $1.00 \pm 0.25^{b}$ & 2.86 & 0.88 & 0.38 \\
\hline $2 \mathrm{~S} / \mathrm{Cl}$ & $0.78 \pm 0.09^{b}$ & $3.94 \pm 1.13^{\mathrm{a}}$ & 0.93 & 8.63 & 4.44 \\
\hline $\mathrm{HHV}\left(\mathrm{MJ} \cdot \mathrm{kg}^{-1} \mathrm{DM}\right)$ & $18.57 \pm 0.40^{b}$ & $19.61 \pm 0.55^{\mathrm{a}}$ & 17.97 & 18.68 & 20.42 \\
\hline $\mathrm{LHV}\left(\mathrm{MJ} \cdot \mathrm{kg}^{-1} \mathrm{DM}\right)$ & $17.51 \pm 0.40^{b}$ & $18.43 \pm 0.52^{\mathrm{a}}$ & 16.72 & 17.41 & 19.18 \\
\hline
\end{tabular}

HHV: higher heating value; LHV: lower heating value; ${ }^{1}$ first of two cuts, ash concentration taken and indices calculated from [12]; ${ }^{2}$ calculated from [15]; ${ }^{\mathrm{a}, \mathrm{b}}$ Different letters indicate significant differences between silage and press cake from sports fields.

The IFBB process increased the lower and the higher heating values by about $1 \mathrm{MJ} \cdot \mathrm{kg}^{-1} \mathrm{DM}$, which is a rather large increase in comparison to semi-natural grassland [18]. However, lower and higher heating values were not as high as the values for coniferous wood [15].

The $\mathrm{K}_{2} \mathrm{O} / \mathrm{CaO}$ index of silage and press cake from sports fields was higher than the index of the corresponding materials from roadside verges, indicating an increased fouling tendency. The IFBB process reduced the index significantly; however, it was still high compared to coniferous wood $(0.38$, calculated from [15]), leaf litter (0.25 [19]), and press cake from semi-natural grassland (0.50 [3]). 
The $2 \mathrm{~S} / \mathrm{Cl}$ index in press cake from sports fields (3.94) was higher than in corresponding silage (0.78) or in silage from urban roadside verges (0.93). However, it was not as high as in the press cake from the grass of roadside verges (8.63 [12]) or in coniferous wood (4.44 calculated from [15]). Sommersacher et al. [4] suggest a $2 \mathrm{~S} / \mathrm{Cl}$ ratio of $>4$ in order to assume only a minor corrosion risk. This value was nearly reached by the press cake from sports fields. Yet, Khalsa at al. [20] reported $2 \mathrm{~S} / \mathrm{Cl}$ ratios $>10$ for urban grass and leaf litter after a leaching process.

\subsection{Anaerobic Digestion Related Properties of Silage and Press Fluid}

Methane yield from the press fluid was significantly higher $\left(340.10 \mathrm{l}_{\mathrm{N}} \cdot \mathrm{kg}^{-1} \mathrm{VS}\right)$ than that from the corresponding silage from sports fields $\left(291.86 \mathrm{l}_{\mathrm{N}} \cdot \mathrm{kg}^{-1} \mathrm{VS}\right.$, Table 2). These yields are well above known values for urban grass from roadside verges cut at a lower frequency [21]. Maturity of material is reflected by fiber concentrations, as, e.g., observed by Herrmann et al. [22] and McEniry et al. [17] for different stands cut at different dates throughout the year. Silage from sports fields has lower NDF (neutral detergent fiber), ADF (acid detergent fiber), and ADL (acid detergent lignin) concentrations $(44.47 \%, 24.07 \%$, and $1.24 \% \mathrm{DM}$, respectively) than silage from roadside verges $(57.04 \%, 33.84 \%$, and $4.50 \%$ DM, respectively). Herrmann et al. [22] measured crude fiber concentrations below $30 \%$ DM for grass cut in May. The authors found clear relationships between crude fiber concentrations and methane yields; therefore, the highest methane yields were produced by material cut in May $\left(365 \mathrm{l}_{\mathrm{N}} \cdot \mathrm{kg}^{-1} \mathrm{VS}\right)[22]$.

Table 2. Anaerobic digestion related properties of grass from urban proveniences. Standard deviations are given.

\begin{tabular}{ccccc}
\hline Parameter & $\begin{array}{c}\text { Silage from } \\
\text { Sports Fields }\end{array}$ & $\begin{array}{c}\text { Press Fluid from } \\
\text { Sports Fields }\end{array}$ & $\begin{array}{c}\text { Silage from Urban } \\
\text { Roadside Verges }\end{array}$ & $\begin{array}{c}\text { Press Fluid from Urban } \\
\text { Roadside Verges }\end{array}$ \\
\hline Number of samples & 18 & $17^{3}$ & 10 & 10 \\
NDF (\% DM) & $44.47 \pm 4.76$ & -2 & 57.04 & - \\
ADF (\% DM) & $24.07 \pm 1.95$ & - & 33.84 & - \\
ADL (\% DM) & $1.24 \pm 0.26$ & - & 4.50 & 1.41 \\
Dry matter (\% FM) & $32.79 \pm 11.05^{\mathrm{a}}$ & $2.48^{\mathrm{b}} \pm 0.72$ & 25.99 & 93.9 \\
Volatile solids (\% DM) & $87.27 \pm 2.50^{\mathrm{a}}$ & $78.04^{\mathrm{b}} \pm 3.48$ & 53.9 & 60 \\
Methane concentration (\% of biogas) & $58.38 \pm 3.64^{\mathrm{b}}$ & $64.13^{\mathrm{a}} \pm 4.18$ & 56 & 221 \\
Methane yield $\left(\mathrm{l}_{\mathrm{N}} \cdot \mathrm{kg}^{-1} \mathrm{VS}\right)$ & $291.86 \pm 34.36^{\mathrm{b}}$ & $340.10^{\mathrm{a}} \pm 56.73$ & 292 \\
\hline
\end{tabular}

ADF: acid detergent fiber; ADL: acid detergent lignin; NDF: neutral detergent fiber; ${ }^{1}$ first of two cuts, data partly taken from [21]; ${ }^{2}$ not detected; ${ }^{3}$ Number of samples is 17 instead of 18 because one press fluid was accidently spilled; ${ }^{a, b}$ Different letters indicate significant differences between silage and press cake from sports fields.

The methane concentration in biogas produced from press fluid was significantly higher than in biogas from the corresponding silage, whereas concentrations of dry matter and volatile solids were lower. This is in accordance with previous findings for other materials [15]. On the one hand, the mashing process decreases the dry matter content by adding water. On the other hand, the process directs minerals into the press fluid, whereby the ash concentration is increased and, as a consequence, the concentration of volatile solids (VSs) is decreased.

\subsection{Economic and Ecological Potential of Biomass from Sports Fields as a Substrate for Bioenergy Generation}

The biomass potential from sports fields is uncertain. The city of Kassel (Germany) has a total area of 10,700 ha and contains 28 sports fields [23], while the city of London (UK) has a total area of about 157,200 ha and contains about 1500 sports fields [24]. Assuming an average size of each field of 1 ha, the share of sports fields is less than $1 \%$ of the total area of either of these two cities. Therefore, it seems unlikely that the exclusive recovery of grass from sports fields can be economically viable. However, there are several biomass types occurring in cities, e.g., grass from parks and roadside verges as well as leaf litter. Some information about these materials is already available and is generally promising regarding energetic recovery $[7,12,19,21]$. Therefore, grass from sports fields could be handled as a co-substrate. 
Hidaka et al. [25] investigated the possibility of co-digesting clipped urban grass with sewage sludge and measured methane yields of 90 to $200 \mathrm{l}_{\mathrm{N}} \cdot \mathrm{kg}^{-1} \mathrm{VS}$ from grass depending on the digestion technique. However, the material was derived from un-maintained areas, which presumably contained relatively high fiber concentrations.

To assess the ecological sustainability of utilizing biomass from sports fields in bioenergy generation, a sound modeling of harvesting opportunities is needed. Sports fields are generally rather dispersed over a city's area, and harvesting would probably entail higher energy costs compared to known values for agriculture. However, it must be taken into account that the material has to be mowed and disposed of regardless of further utilization. Therefore, an energy balance which achieves a compensation of energy input and output is already an improvement over the current situation.

\section{Materials and Methods}

\subsection{Sampling}

Samples were derived from 4 sports fields within the city of Kassel in 2015. The city of Kassel has about 200,000 inhabitants and is located in the middle of Germany. Sports fields are spread across the city's area. They differ in fertilization scheme and soil construction (Figure 2). Three were installed on natural soil, while one field was constructed according to a professional standard (e.g., sub-construction and drainage, so-called DIN construction).

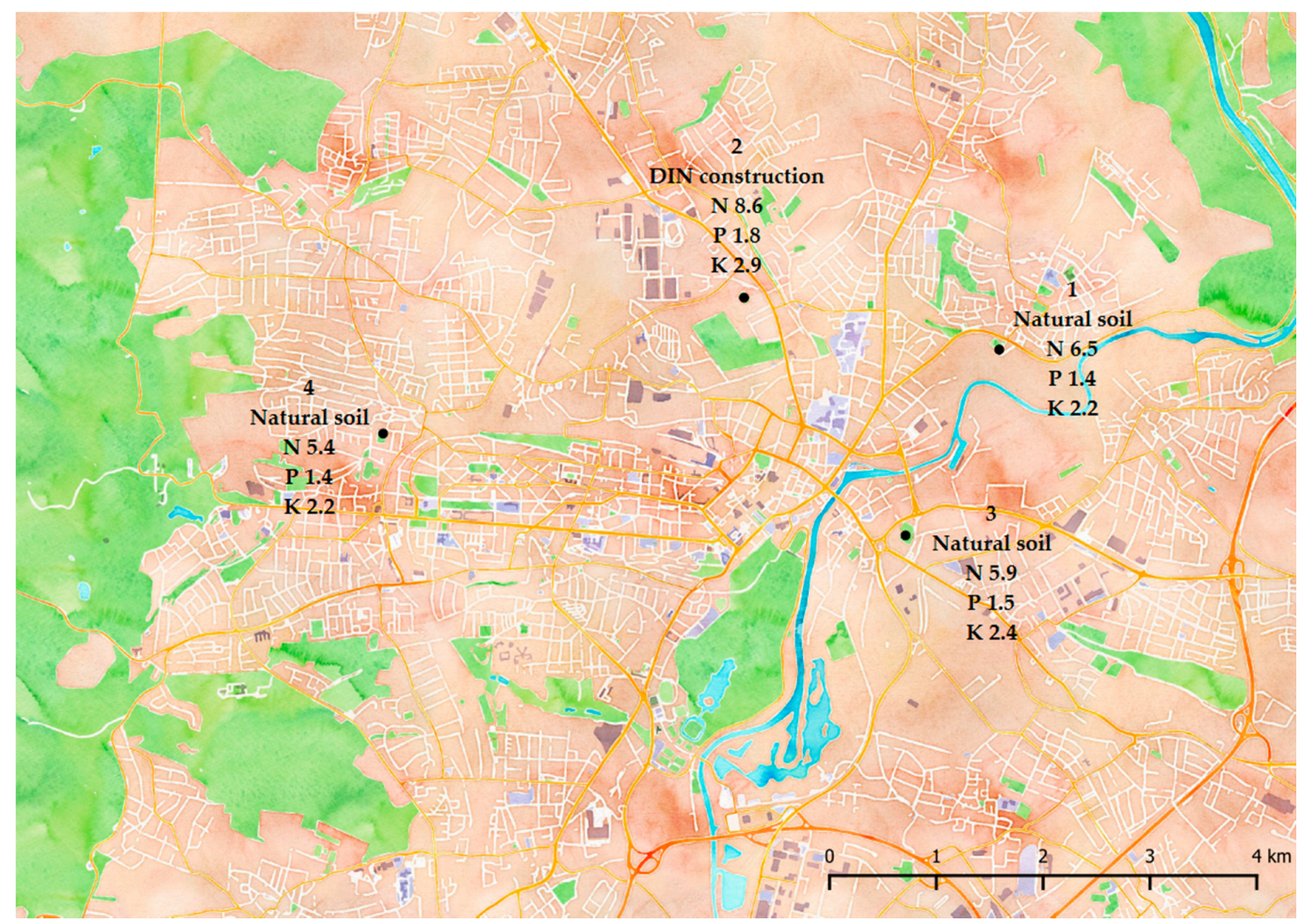

Figure 2. Location of investigated sports fields within the city of Kassel. Soil construction and fertilization in spring 2015 is given. N, P, and $\mathrm{K}$ fertilization refers to $\mathrm{g} \cdot \mathrm{m}^{-2}$. year $^{-1}$. Underlying map: OpenStreetMap contributors [26].

Vegetation analysis was conducted in July at 5 randomly selected plots in each field. Diversity was low, with 11 detected species in total (Table 3). Lolium perenne was the main species, which occurred with a mean degree of coverage of about $50 \%$. Poa trivialis (mean degree of coverage $30 \%$ ) and Trifolium repens (mean degree of coverage $20 \%$ ) were also observed on every field. 
Sports fields are mowed weekly during the vegetation period. In the main growing periods, the cut biomass is removed from the fields. We took samples in Calendar Weeks 28, 29, 30, 32, and 33. From Sports Field 4, no samples could be taken in Calendar Weeks 29 and 33 due to a lack of sufficient biomass. Grass was cut and collected with a commercial ride-on mower. Subsequently, we ensiled the biomass in $60 \mathrm{~L}$ airtight polyethylene barrels for a minimum of 3 months. For each sample, we filled one barrel with biomass bit by bit and compressed the material by stamping between additions. Therefore, each of the 18 samples consisted of $60 \mathrm{~L}$ of compressed biomass.

Table 3. Vegetation analysis of 4 sports fields conducted in July 2015. Degree of coverage is given in \%.

\begin{tabular}{ccccc}
\hline \multirow{2}{*}{ Species } & \multicolumn{4}{c}{ Sports Field } \\
\cline { 2 - 5 } & $\mathbf{1}$ & $\mathbf{2}$ & $\mathbf{3}$ & $\mathbf{4}$ \\
\hline Agrostis spec. & - & - & 30 & - \\
Elymus repens & - & - & 10 & - \\
Lolium perenne & 65 & 20 & 55 & 40 \\
Poa spec. & 20 & 85 & 45 & 70 \\
Bellis perennis & - & 10 & - & - \\
Plantago major & - & - & 10 & 5 \\
Polygonum aviculare & - & - & 10 & - \\
Taraxacum spec. & - & 5 & 5 & - \\
Trifolium repens & 40 & 30 & 10 & 10 \\
\hline
\end{tabular}

\subsection{Processing}

After ensiling, subsamples were taken from every barrel for dry matter (DM) and ash determination, as well as for elemental and fiber analysis. Remaining silage was treated with the IFBB technique. This involved mixing the biomass with warm water $\left(40^{\circ} \mathrm{C}\right)$ at a $1: 4$ ratio (material/water, on a fresh matter basis) in a modified concrete mixer heated with natural gas burners and stirred for $15 \mathrm{~min}$ at constant temperature. Subsequently, the material was squeezed by a screw press (type AV, Anhydro Ltd., Kassel, Germany) with a pitch of 1:6 and a rotation speed of 6 rpm, resulting in a press cake and a press fluid. The cylindrical screen encapsulating the screw had a perforation of $1.5 \mathrm{~mm}$. Press fluids were frozen at $-20^{\circ} \mathrm{C}$ for later anaerobic digestion. Dry matter, ash, and element concentrations in the press cake were determined according to the procedure applied for silage.

\subsection{Anaerobic Digestion}

Digestion experiments were conducted in stirred batches following the experimental set-up of Zerr [27], taking the German standard into account [28]. After thawing the substrates (silage and press fluid) for $60 \mathrm{~h}$ at room temperature $\left(\sim 20^{\circ} \mathrm{C}\right), 400 \mathrm{~g}$ of silage, $3.6 \mathrm{~kg}$ of potable water, and $8 \mathrm{~kg}$ of inoculum (digested slurry from a biogas plant, stored under mesophilic conditions) were mixed. For the press fluids, $4 \mathrm{~kg}$ of press fluid and $8 \mathrm{~kg}$ of inoculum were mixed. Mixtures were digested in gas-proof $20 \mathrm{~L}$ polyethylene containers at mesophilic temperature $\left(37 \pm 1^{\circ} \mathrm{C}\right)$ with 2 replicates of silage and 3 replicates of press fluid mixtures. Two replicates of pure inoculum were digested separately to subtract the methane yield of the inoculum from the total methane produced in inoculated samples and thereby calculate the actual yield from the sample. Biogas was collected in gas-proof bags, and volume was measured with a wet drum gas meter (TG5; Ritter Apparatebau GmbH, Bochum, Germany) at Digestion Days 1, 2, 3, 4, 7, 9, 11, 14, 16, 18, and 21 for press fluids and additionally on Days 24, 28, 31 and 35 for silage. While digesting, samples were stirred every $3 \mathrm{~h}$ for $15 \mathrm{~min}$ with a U-shaped stirrer driven by a $12 \mathrm{~V}$ direct current motor. After 21 and 35 days, respectively, daily biogas production from press fluid and silage was $1 \%$ of total biogas production at this time. 


\subsection{Chemical Analysis}

Dry matter was determined by drying the biomass at $105^{\circ} \mathrm{C}$ for $48 \mathrm{~h}$. Ash content was determined by incineration in a muffle furnace at $550{ }^{\circ} \mathrm{C}$. Biomass for elemental and fiber analysis was dried at $65{ }^{\circ} \mathrm{C}$, ground with a cutting mill (SM 1, Retsch $\mathrm{GmbH}$, Haan, Germany) to pass a $5 \mathrm{~mm}$ sieve, and subsequently ground with a sample mill (1093 Cyclotec, Foss GmbH, Hamburg, Germany) to $1 \mathrm{~mm}$.

Concentrations of $\mathrm{Ca}, \mathrm{Cl}, \mathrm{Cu}, \mathrm{Fe}, \mathrm{K}, \mathrm{Mg}, \mathrm{Mn}, \mathrm{Na}, \mathrm{P}, \mathrm{S}$, and $\mathrm{Zn}$ were measured by $\mathrm{X}$-ray fluorescence analysis. $\mathrm{C}, \mathrm{H}$, and $\mathrm{N}$ concentrations were determined with an elemental analyzer (Vario Max $\mathrm{CHN}$; Elementar Analysesysteme $\mathrm{GmbH}$, Hanau, Germany) using $150 \mathrm{mg}$ of dried material.

Fiber analysis was conducted with a fiber analyzer (ANKOM A220; Ankom Technology, Macedon, NY, USA) in accordance with operating instructions. Subsamples of about $0.5 \mathrm{~g}$ were sealed in a filter bag and subsequently boiled with a neutral detergent solution and alpha-amylase for neutral detergent fiber (NDF) determination. We decided to renounce the use of $\mathrm{Na}_{2} \mathrm{SO}_{3}$ because it regularly leads to an underestimation of NDF due to the loss of lignin [29]. For acid detergent fiber (ADF) determination, filter bags were boiled with acid detergent solution and water and subsequently rinsed with acetone. Acid detergent lignin (ADL) analysis was conducted by adding $\mathrm{H}_{2} \mathrm{SO}_{4}$ solution, washing with water, and then adding a $\mathrm{NaOH}$ solution. Filter bags were then washed with hot water and rinsed with acetone. Finally, filter bags were incinerated in a muffle furnace at $550^{\circ} \mathrm{C}$. NDF, ADF, and ADL concentrations were calculated as

$$
\text { Fiber type }[\% \text { of } \mathrm{DM}]=\frac{\left(\mathrm{m}_{3}-\left(\mathrm{m}_{1} \times \mathrm{C}\right)\right) \times 100}{\mathrm{~m}_{2} \times \mathrm{DM}}
$$

where $m_{1}$ is the mass of the empty filter bag, $m_{2}$ is the mass of the sample, $m_{3}$ is the mass of organic matter after boiling and incineration, and C is the "blank-bag correction" factor, which indicates the mass change of the filter bag during processing.

Methane concentration in the biogas was analyzed with a gas analyzer (GS IRM100; GS Messtechnik $\mathrm{GmbH}$, Ratingen, Germany). Methane yield was standardized to normalized conditions (273.15 K, $1013.25 \mathrm{hPa}$ ) and related to the mass of volatile solids (VSs). Volatile solids were defined as the mass loss of material during incineration in a muffle furnace at $550{ }^{\circ} \mathrm{C}$ subsequent to drying at $105^{\circ} \mathrm{C}$ in a drying oven. Since parts of the volatile solids are lost during drying due to high volatility [30], the total amount of volatile solids in silage was corrected by applying the formula [31]

$$
\mathrm{VS}_{\text {corrected }}[\%]=2.08+0.975 \times \mathrm{VS}_{\text {uncorrected }}[\%] .
$$

To correct the amount of volatile solids in the press fluid, we assumed the same fraction of highly volatile substances as calculated above for the corresponding silages since VSs have the same mass flow as water in the press fluid because most (e.g., short fatty acids and alcohols) are highly water-soluble.

\subsection{Further Calculations and Statistics}

From $\mathrm{C}, \mathrm{H}$, and $\mathrm{N}$ concentrations, the higher heating value (HHV) was calculated as [32]

$$
\mathrm{HHV}\left[\frac{\mathrm{MJ}}{\mathrm{kg} \mathrm{DM}}\right]=\frac{3.55 \mathrm{C}^{2}-232 \mathrm{C}-2230 \mathrm{H}+51.2 \mathrm{C} \times \mathrm{H}+131 \mathrm{~N}+20,600}{1000} .
$$

Lower heating value (LHV) was calculated from the higher heating value (HHV) by applying the formula:

$$
\operatorname{LHV}\left[\frac{\mathrm{MJ}}{\mathrm{kg} \mathrm{DM}}\right]=\mathrm{HHV}-\left(8.937 \times \frac{\mathrm{H} \% \mathrm{DM}}{100}\right) \times 2.2
$$

where 8.937 is the mass share of hydrogen in a water molecule and 2.2 is the enthalpy of water vaporization. 
From $\mathrm{K}$ and $\mathrm{Ca}$ concentrations, the $\mathrm{K}_{2} \mathrm{O} / \mathrm{CaO}$ index was calculated, taking the molar mass of oxides into account [3]:

$$
\frac{\mathrm{K}_{2} \mathrm{O}}{\mathrm{CaO}} \text { Index }=\frac{\mathrm{K} \times \frac{(2 \times 39.1+16)}{2 \times 39.1}}{\mathrm{Ca} \times \frac{(40.08+16)}{40.08}} .
$$

From $\mathrm{S}$ and $\mathrm{Cl}$ concentrations, the $2 \mathrm{~S} / \mathrm{Cl}$ index was calculated, taking the molar mass of each into account [4]:

$$
\frac{2 \mathrm{~S}}{\mathrm{Cl}} \text { Index }=\frac{\frac{\mathrm{S}}{32} \times 2}{\frac{\mathrm{Cl}}{35.5}} .
$$

Figure 1 was generated by applying QuantumGIS 2.12.0, while the other figures were generated with R 2.15.3 [33].

To identify differences in element and fiber concentrations as well as methane yields between harvesting dates and sites, the mixed model procedure MIXED was conducted using SAS 9.2 with harvest date treated as a nested effect within fields or with fields treated as a nested effect within harvest. Least-squares means were adjusted with the studentized maximum modulus method to account for multiple tests and used to detect fixed effects among harvests, taking the covariance structure into account. Covariance parameters were estimated by a likelihood-based method (restricted maximum likelihood) referring to a first-order autoregressive model (AR (1)). Denominator degrees of freedom were estimated according to a Satterthwaite approximation.

Applying the non-parametric Wilcoxon's rank-sum test, the $\mathrm{R}$ software was used to detect differences in element and ash concentration between materials or proveniences, as well as differences in methane yield between silage and press fluid.

\section{Conclusions}

Favorable heating values and methane yields can be expected from the utilization of grass from sports fields in energy generation. However, mineral concentrations are high, which may lead to technical problems in combustion. Mineral concentrations might be decreased by the IFBB process, though values (e.g., Cl, N, S) are still alarming. Therefore, the combustion of grass clippings from sports fields seems only feasible in mixtures with materials containing fewer minerals (e.g., wood, leaf litter) and thus could be part of an integrated energy approach for a city's green areas. Alternatively, co-digestion in nearby sewage water treatment plants or biogas plants could be considered.

Acknowledgments: We received funds by the Deutsche Forschunsgemeinschaft (DFG) for covering the costs to publish in open access.

Author Contributions: Meike Nitsche and Frank Hensgen conceived of and designed the experiments; Frank Hensgen performed the experiments; Meike Nitsche and Michael Wachendorf analyzed the data; Meike Nitsche wrote the paper.

Conflicts of Interest: The authors declare no conflict of interest.

\section{References}

1. Pick, D.; Dieterich, M.; Heintschel, S. Biogas Production Potential from Economically Usable Green Waste. Sustainability 2012, 4, 682-702. [CrossRef]

2. Jenkins, B.M.; Baxter, L.L.; Miles, T.R., Jr.; Miles, T.R. Combustion properties of biomass. Fuel Process. Technol. 1998, 54, 17-46. [CrossRef]

3. Bühle, L.; Dürl, G.; Hensgen, F.; Urban, A.; Wachendorf, M. Effects of hydrothermal conditioning and mechanical dewatering on ash melting behaviour of solid fuel produced from European semi-natural grasslands. Fuel 2014, 118, 123-129. [CrossRef]

4. Sommersacher, P.; Brunner, T.; Obernberger, I. Fuel Indexes: A Novel Method for the Evaluation of Relevant Combustion Properties of New Biomass Fuels. Energy Fuels 2012, 26, 380-390. [CrossRef]

5. Thamsiriroj, T.; Murphy, J.D. Difficulties Associated with Monodigestion of Grass as Exemplified by Commissioning a Pilot-Scale Digester. Energy Fuels 2010, 24, 4459-4469. [CrossRef] 
6. Prochnow, A.; Heiermann, M.; Plöchl, M.; Linke, B.; Idler, C.; Amon, T.; Hobbs, P. Bioenergy from permanent grassland-A review: 1. Biogas. Bioresour. Technol. 2009, 100, 4931-4944. [CrossRef] [PubMed]

7. Hensgen, F.; Richter, F.; Wachendorf, M. Integrated generation of solid fuel and biogas from green cut material from landscape conservation and private households. Bioresour. Technol. 2011, 102, 10441-10450. [CrossRef] [PubMed]

8. Prochnow, A.; Heiermann, M.; Plöchl, M.; Amon, T.; Hobbs, P. Bioenergy from permanent grassland-A review: 2. Combustion. Bioresour. Technol. 2009, 100, 4945-4954. [CrossRef] [PubMed]

9. McEniry, J.; O'Kiely, P. Anaerobic methane production from five common grassland species at sequential stages of maturity. Bioresour. Technol. 2013, 127, 143-150. [CrossRef] [PubMed]

10. Geber, U. Cutting frequency and stubble height of reed canary grass (Phalaris arundinacea L.): Influence on quality and quantity of biomass for biogas production. Grass Forage Sci. 2002, 57, 389-394. [CrossRef]

11. Triolo, J.M.; Pedersen, L.; Qu, H.; Sommer, S.G. Biochemical methane potential and anaerobic biodegradability of non-herbaceous and herbaceous phytomass in biogas production. Bioresour. Technol. 2012, 125, $226-232$. [CrossRef] [PubMed]

12. Piepenschneider, M.; de Moor, S.; Hensgen, F.; Meers, E.; Wachendorf, M. Element concentrations in urban grass cuttings from roadside verges in the face of energy recovery. Environ. Sci. Pollut. Res. 2015, 22, 7808-7820. [CrossRef] [PubMed]

13. El-Nashaar, H.; Griffith, S.; Steiner, J.; Banowetz, G. Mineral concentration in selected native temperate grasses with potential use as biofuel feedstock. Bioresour. Technol. 2009, 100, 3526-3531. [CrossRef] [PubMed]

14. McEniry, J.; Finnan, J.; King, C.; O'Kiely, P. The effect of ensiling and fractionation on the suitability for combustion of three common grassland species at sequential harvest dates. Grass Forage Sci. 2012, 67, 559-568. [CrossRef]

15. Obernberger, I.; Brunner, T.; Barnthaler, G. Chemical properties of solid biofuels-Significance and impact. Biomass Bioenergy 2006, 30, 973-982. [CrossRef]

16. Nitsche, M.; Nurmatov, N.; Hensgen, F.; Wachendorf, M. Heavy Metals and Polycyclic Aromatic Hydrocarbons in Urban Leaf Litter Designated for Combustion. Energies 2017, 10, 298. [CrossRef]

17. McEniry, J.; King, C.; O'Kiely, P. Silage fermentation characteristics of three common grassland species in response to advancing stage of maturity and additive application. Grass Forage Sci. 2014, 69, 393-404. [CrossRef]

18. Bühle, L.; Hensgen, F.; Donnison, I.; Heinsoo, K.; Wachendorf, M. Life cycle assessment of the integrated generation of solid fuel and biogas from biomass (IFBB) in comparison to different energy recovery, animal-based and non-refining management systems. Bioresour. Technol. 2012, 230-239. [CrossRef] [PubMed]

19. Piepenschneider, M.; Nurmatov, N.; Bühle, L.; Hensgen, F.; Wachendorf, M. Chemical Properties and Ash Slagging Characteristics of Solid Fuels from Urban Leaf Litter. Waste Biomass Valoriz. 2016, 7, 625-633. [CrossRef]

20. Khalsa, J.; Döhling, F.; Berger, F. Foliage and Grass as Fuel Pellets-Small Scale Combustion of Washed and Mechanically Leached Biomass. Energies 2016, 9, 361. [CrossRef]

21. Piepenschneider, M.; Bühle, L.; Hensgen, F.; Wachendorf, M. Energy recovery from grass of urban roadside verges by anaerobic digestion and combustion after pre-processing. Biomass Bioenergy 2016, 85, 278-287. [CrossRef]

22. Herrmann, C.; Prochnow, A.; Heiermann, M.; Idler, C. Biomass from landscape management of grassland used for biogas production: Effects of harvest date and silage additives on feedstock quality and methane yield. Grass Forage Sci. 2014, 69, 549-566. [CrossRef]

23. Stadt Kassel. Sport in Kassel. 2016. Available online: http://www.kassel.de/miniwebs/sport_in_kassel/ 20757/index.html (accessed on 14 January 2017).

24. London Playing Fields Foundation. Who We Are. 2016. Available online: http://lpff.org.uk/About/WhoWe-Are (accessed on 28 December 2016).

25. Hidaka, T.; Arai, S.; Okamoto, S.; Uchida, T. Anaerobic co-digestion of sewage sludge with shredded grass from public green spaces. Bioresour. Technol. 2013, 130, 667-672. [CrossRef] [PubMed]

26. OpenStreetMap contributors. Open Layers Plugin. Available online: http://www.openstreetmap.de (accessed on 10 January 2017).

27. Zerr, W. Versuchsanlage zur energetischen Beurteilung von Substraten und Kofermentaten für Biogasanlagen. Umweltwissenschaften Schadstoff Forschung 2006, 18, 219-227. [CrossRef] 
28. Verein Deutscher Ingenieure. VDI 4630 Vergärung Organischer Stoffe: Substratcharakterisierung, Probenahme, Stoffdatenerhebung, Gärversuche; Beuth: Berlin, Germany, 2006.

29. Van Soest, P.J.; Wine, R.H. Use of detergents in the analysis of fibrous feeds. IV. Determination of plant cell-wall constituents. J. Assoc. Off. Anal. Chem. 1967, 50, 50-55.

30. Porter, M.G.; Murray, R.S. The volatility of components of grass silage on oven drying and the inter-relationship between dry-matter content estimated by different analytical methods. Grass Forage Sci. 2001, 56, 405-411. [CrossRef]

31. Weißbach, F.; Kuhla, S. Substance losses in determining the dry matter content of silage and green fodder: Arising errors and possibilities of correction. Übers. Tierernährung 1995, 23, 189-214.

32. Friedl, A.; Padouvas, E.; Rotter, H.; Varmuza, K. Prediction of heating values of biomass fuel from elemental composition. Anal. Chim. Acta 2005, 544, 191-198. [CrossRef]

33. R Core Team. R: A language and Environment; R Foundation for Statistical Computing: Vienna, Austria, 2013.

(C) 2017 by the authors. Licensee MDPI, Basel, Switzerland. This article is an open access article distributed under the terms and conditions of the Creative Commons Attribution (CC BY) license (http://creativecommons.org/licenses/by/4.0/). 